\title{
Obituary
}

\section{Dr G. A. Reay}

George AdAm ReAy, formerly director of the Torry Research Station, Aberdeen, died on January 20 after a brief illness. He was sixty-nine.

He was one of the small, enthusiastic and outstanding team of British workers which, initially under the leadership of the late Sir William Bate Hardy, pioneered the study of the various aspects of food science and technology. $\mathrm{He}$ obtained his MA (1921) and BSc (1923) at Aberdeen University and won a Senior Kilgour Scholarship. In 1924 he was awarded a Studentship of Emmanuel College, Cambridge, and studied aspects of pancreatic activity and carbohydrate metabolism under the late Sir Frederick Gowland Hopkins at the Sir William Dunn Institute. He was awarded a Carnegie Research Fellowship in 1926 and obtained his PhD (Cantab) in 1927.

In September of the same year he joined the Food Investigation Organization of the Department of Scientific and Industrial Research and was posted to Aberdeen to study the possibility of improving methods of handling "white" fish at sea. It was characteristic of the man that he began his investigations at sea on commercial trawlers rather than in the laboratory; this early work threw much needed light on some of the basic factors affecting spoilage and it led to recommendations for good handling practice that have required little modification over the years. When Torry Research Station was opened in 1929, Reay had already gained valuable field and research experience in freezing and cold storage; he was one of the first to stress the importance of low temperature storage to obtain a good product, as well as rapid freezing, a view at variance with contemporary thinking, and he led the work on freezing at sea, which was first applied commercially in the early 1960 s.

Dr Reay is survived by his wife, son and daughter.

\section{Academician \\ A. I. Alikhanov}

THE death occurred, on December 8, 1970, of Academician Abram Isaakovich Alikhanov, one of the leading physicists of the Soviet Union.

Alikhanov was born in 1904, in Gandzha (now Kirovabad), in Azerbaijan. He was educated at the Leningrad Polytechnic Institute. After his graduation in 1931, he specialized in nuclear physics and cosmic radiation. In 1934-37 he was the first to study the basic laws of positron formation by means of gamma rays, and investigated problems of beta-decay. With his brother, Artemii Isaakovich Alikhanyan, he began a programme of systematic study of the beta-spectra of synthetic radioactive elements. During World War II, he set up a laboratory in Armenia where he developed a new method of studying the composition and energy spectra of cosmic rays.

In 1945, Alikhanov founded the Institute of Theoretical and Experimental Physics, remaining as its director until 1968. There, he and his brother developed a large spectrometer for studying the mass spectra of cosmic ray particles. In 1949 he put into operation the first Soviet reactor with a heavy water inhibitor, and was one of the designers of the first Soviet atomic bomb. In 1961, on his initiative, the Institute of Theoretical and Experimental Physics produced a $7 \mathrm{GeV}$ proton synchrotron, and he later took a leading part in the development of the Serpukhov $70 \mathrm{GeV}$ proton accelerator.

$\mathrm{He}$ was elected to the Academy of Sciences of the Soviet Union and the Armenian Academy of Sciences in 1943, and became Chairman of the Commission for the Study of Cosmic Rays of the Academy of Sciences of the USSR in 1959. His publications include Investigation of Artificial Radioactivity (1936), New Data on the Nature of Cosmic Radiation (1945), Cosmic Radiation (1949), Weak Interactions (1960) and Experiment (1962). He was awarded the Order of Lenin three times, a State Prize for physics and a number of medals.

\section{Announcements}

\section{University News}

The Council of the University of Birmingham has approved the appointment of a review body "to consider the role, constitution and functioning of the University of Birmingham and to make recommendations to Council for any desirable changes". The review body would now welcome written submissions of evidence from any person or organization concerning any part of the matter within its terms of reference. Written evidence should be sent to the secretary, Sir Maurice Dean, Winterbourne, 58 Edgbaston Park Road, Birmingham B15 2RT, not later than March 31. Persons or representatives of organizations may later be invited to appear before the review body.

\section{Appointments}

Professor Henry Charnock, University of Southampton, has been appointed director of the National Institute of Oceanography in succession to Sir George Deacon.

\section{Miscellaneous}

The Zoological Society of London has made the following awards for 1970: the Stamford Raffles award, to $\mathbf{M r} \mathbf{D}$. R. Rosevear, an amateur zoologist, for his contributions to the knowledge of West African mammalian fauna; the scientific medal, to Dr Denis Noble, University of Oxford, for his work on the physiology of nerve and muscle and to Professor J. G. Phillips, University of Hull, for his work on comparative zoology; the Thomas Henry Huxley award, to Dr P. J. Sharp, University of Leeds, for his doctoral thesis "The hypothalamic control of gonadotrophin release in the Japanese quail (Coturnix coturnix japonica)"; a certificate will be presented to Dr $\mathbf{O}$. Anne E. Rosa, University of London, whose doctoral thesis was highly commended; the Prince Philip prize, to Stephen M. Clift, Archbishop Holgate's Grammar School, York, for his essay "Some characteristics of the shells of limpets, Patella vulgata, in relation to the environment".

ERratum. In the article "Menstrual Synchrony and Suppression" by Martha K. McClintock (Nature, 229, 244; 1971), the last sentence of the fourth paragraph should read: "In addition, subjects estimated how many times each week they spent time with males (for example, dating, visiting informally or conversing at length with male professors) and listed by room number the girls $(N \leq 10)$ with whom they spent the most time, indicating which two of these they saw most often".

\section{International Meetings}

April 5-6, Flames, Flammability and Fires, Swansea (Professor D. F. Cullis, Department of Chemistry, The City University, London EC1).

April 6, New Materials and Trends in the Water Industry, London (Mr E. S. Hall, 69 Disraeli Crescent. High Wycombe, Buckinghamshire).

April 14-16, Tissue Growth and Interaction during Development and Interactive Behaviour of Cells. Aberystwyth (Professor Bryn Jones, Department of Zoology, University College of Wales, Aberystwyth, Wales).

May 12. Environmental Health, Detroit (Alan J. Hitsky, Information Services, Wayne State University, Detroit, Michigan 48202, USA). 